\title{
The Role of Nonhemoglobin Proteins and Reduced Glutathione in the Protection of Hemoglobin from Oxidation In Vitro*
}

\author{
A. S. Hill, Jr., A. Haut, G. E. Cartwright, and M. M. Wintrobe \\ (From the Department of Medicine, University of Utah College of Medicine, \\ Salt Lake City, Utah)
}

A deficiency of reduced glutathione in erythrocytes of freshly shed blood (1-4) or in erythrocytes exposed to certain chemical compounds (5) has been associated with shorter red cell survival and, in most cases, with the accumulation of oxidation products of hemoglobin, including methemoglobin, sulfhemoglobin, and Heinz bodies. Studies of "primaquine-sensitive" hemolytic disease have emphasized as a characteristic feature an "unstable" reduced glutathione (GSH) in the red cells, attributed to limited availability of reduced TPN (TPNH), the result, in turn, of a deficiency of the enzyme, glucose-6-phosphate dehydrogenase (G6PD). Despite extensive studies of G6PD deficiency, it is still uncertain whether the observations on reduced glutathione are of pathogenetic significance or are incidental. There is even less information on the role of glutathione in certain cases of congenital methemoglobinemia (1) and in hemolytic disease with $(3,4,6)$ or without $(\dot{2})$ inclusion bodies, which have been associated with abnormalities of glutathione. Although these cases may suggest that reduced glutathione in the erythrocyte may be the final conımon pathway for various disorders affecting oxidative hemolysis, the evidence conflicts as to how, if at all, glutathione protects the healthy erythrocyte from oxidative hemolysis.

Mills (7-9) and Randall (7), after studies of rat blood, concluded that GSH protects hemoglobin from deleterious oxidative agents only in the presence of an additional factor, an enzyme they termed glutathione peroxidase. Studies of

* Submitted for publication November 9, 1962 ; accepted September 12, 1963.

This investigation was supported by a research grant (AM-04489) and a graduate training grant (T1 AM5098) from the National Institute of Arthritis and Metabolic Diseases, U. S. Public Health Service, Bethesda, Md. human erythrocytes by Allen and Jandl (10) led these authors to conclude that GSH per se protects hemoglobin from oxidation and that no additional factors are required; conversely, Szeinberg and Marks (11) found that GSH affords no protection to human hemoglobin against oxidative changes. The earlier report of Foulkes and Lemberg (12) that GSH might oxidize hemoglobin, along with the studies by Szeinberg and Marks (11) and Allen and Jandl (10), casts doubt on the applicability to humans of the concept $(13,14)$, based on studies of rat blood $(7$, 8 ), that an adequate amount of reduced glutathione and the enzyme glutathione peroxidase together protect hemoglobin from oxidative breakdown.

Our experiments demonstrate, by the use of erythrocytes and hemoglobin from human subjects, that in an in vitro system GSH can protect hemoglobin from oxidizing agents and that this protection is dependent upon a nonhemoglobin protein factor of erythrocytes, adduced to be glutathione peroxidase. We further present an experimental basis for reconciliation of the preceding contradictory reports concerning the role of glutathione.

\section{Methods}

Venous blood from hematologically normal and apparently healthy adults was anticoagulated with heparin. Plasma, buffy coat, and uppermost erythrocytes were removed after prompt centrifugation at $5^{\circ} \mathrm{C}$. The remaining red cells were washed three times each with 4 vol of cold Krebs-Ringer phosphate buffer $(7,8)$, then stored at $5^{\circ} \mathrm{C}$, and used as intact erythrocytes within 48 hours.

Preparation of whole hemolysate. Sufficient deionized water ${ }^{1}$ was added to packed washed red cells to hemolyze them and reduce the hemoglobin concentration to

1 Deeminizer, Crystal Research Laboratories, Hartford, Conn. 
about $8 \mathrm{~g}$ per $100 \mathrm{ml}$. The hemolysate was kept at about $5^{\circ} \mathrm{C}$ and was used without further centrifugation within 48 hours of the time of its preparation.

Preparation of hemoglobin solution. Sufficient deionized water was added to washed erythrocytes to hemolyze them and to yield about $8 \mathrm{ml}$ of solution with a hemoglobin concentration of about $10 \mathrm{~g}$ per $100 \mathrm{ml}$. To this was added $15 \mathrm{~g}$ of diethylaminoethyl (DEAE) cellulose from which excess water had been removed. DEAE had been prepared according to the method of Hennessey, Haffner, and Gabrio (15; also Waltersdorph and Huennekens, 16), except for the addition of a final series of washes with deionized water, continued until the supernatant fluid gave a negative phosphate test with silver nitrate. After the mixture of DEAE cellulose and hemolysate was stirred for about 5 minutes, the hemoglobin solution was separated from the cellulose by suction, through the use of a coarse, sintered glass funnel. The filtrate, containing about $8 \mathrm{~g}$ of hemoglobin per $100 \mathrm{ml}$, was the hemoglobin solution employed in these experiments; it was kept cold and used within 48 hours of the time of preparation. The hemoglobin solution was found to be devoid of catalase, G6PD, pyruvate kinase, and glutathione peroxidase activities and to contain carbonic anhydrase activity, each assayed by techniques described below. The whole hemolysate contained all of these enzymatic activities. The nonhemoglobin protein solution, described below, contained all of these activities except carbonic anhydrase.

Preparation of nonhemoglobin protein solution. After extraction of the hemoglobin solution by suction, the cellulose was washed three times in a total of $4,500 \mathrm{ml}$ of cold, deionized water. Excess water was expressed, and the cellulose was treated with $4 \mathrm{ml}$ of $0.4 \mathrm{M}$ phosphate buffer, $\mathrm{pH}$ 7.1. The eluate was separated on a coarse, sintered glass funnel and then was used to reextract the cellulose. The resulting yellow solution was termed the nonhemoglobin protein (NHP) solution. The ratio of the absorbance at $280 \mathrm{~m} \mu$ to that at the Soret band $(420 \mathrm{~m} \mu)$ was $2: 1$ for the NHP solution, whereas that of the hemoglobin solution was $1: 4$.

Preparation of reagents. Preliminary experiments indicated that satisfactory stability of $\mathrm{GSH}^{2}$ could be obtained in $0.15 \mathrm{M}$ sodium chloride or in $0.4 \mathrm{M}$ phosphate buffer $(\mathrm{pH} 7.1)$ if the solutions were prepared within 4 hours of the experiments, if siliconized glassware was used, and if the solutions contained EDTA. All ascorbic acid and acetylphenylhydrazine solutions were adjusted to $\mathrm{pH} 7.1$ with $0.15 \mathrm{M}$ sodium carbonate and were made within 1 hour of their use.

Chemical determinations and enzyme assays. Reduced glutathione was determined by the method used by Mills (9) based on principles outlined by Boyer (17) and also by the technique of Grunert and Phillips (18) as modified by Beutler (19). Oxidized glutathione was determined as reduced glutathione by the same technique, after electrolytic reduction by the method of Dohan and Woodward (20).

\footnotetext{
2 Sigma Chemical Co., St. Louis, Mo.
}

Samples for the determination of hemoglobin pigment were placed in $25-\times 40-\mathrm{mm}$ glass tubes and subjected to $20 \mathrm{kc}$ ultrasound at $4 \mathrm{amp}$ power input at cavitary resonance for 5 seconds. ${ }^{3}$ This insured complete hemolysis and did not affect the proportion of hemoglobin derivatives. The samples, after centrifugation at $2,000 \times g$ for 5 minutes, were clear.

Methemoglobin, sulfhemoglobin, oxyhemoglobin, and total hemoglobin were determined by the method of Evelyn and Malloy (21). Results are expressed as per cent of the total hemoglobin at time zero. "Precipitated hemoglobin" was calculated by subtracting the measured total hemoglobin from the hemoglobin at time zero. In one experiment the precipitated hemoglobin was collected and weighed.

Catalase was determined by the method used by Takahara and co-workers (22), except that the determinations were carried out at $20^{\circ} \mathrm{C}$. Glucose-6-phosphate dehydrogenase was determined in the manner of Kornberg and Horecker (23) as modified by Marks, Szeinberg, and Banks (24). Pyruvate kinase was determined by the method of Bucher and Pfleiderer (25) as modified by Valentine, Tanaka, and Miwa (26). Glutathione peroxidase was determined by a modification of method number two of Mills (9). Carbonic anhydrase was determined by the technique of Wilbur and Anderson (27). Glutathione reductase was determined by the mode of Schrier and co-workers (28).

The data were treated as nonindependent variables. A p value of less than 0.05 was considered to be significant (29).

\section{Results}

Effect of ascorbic acid on the formation of sulfhemoglobin in washed erythrocytes, whole hemolysates, and hemoglobin solutions. The formation of oxidative derivatives of hemoglobin in intact erythrocytes, whole hemolysates, and hemoglobin solutions was zero in 2 hours. Ascorbic acid or acetylphenylhydrazine was therefore added to the incubation flasks to accelerate these oxidative changes, against which the effects of various compounds could be measured.

The augmentation of sulfhemoglobin formation produced by the addition of ascorbic acid was greatest when the substrate was hemoglobin solution, least when the substrate was intact erythrocytes, and intermediate in the case of whole hemolysate (Table I).

Effect of GSH on the formation of sulfhemoglobin in whole hemolysates and hemoglobin solutions incubated with ascorbic acid. GSH had a significant protective effect against the formation

\footnotetext{
3 Branson Instruments, Stamford, Conn.
} 
TABLE I

Sulfhemoglobin formation in erythrocytes, whole hemolysates, and hemoglobin solutions after 1 hour of incubation at $37^{\circ} C^{*}$

\begin{tabular}{lcc}
\hline \hline Substrate & $\begin{array}{c}\text { Ascorbic } \\
\text { acid }\end{array}$ & $\begin{array}{c}\text { Sulfhemo- } \\
\text { globin }\end{array}$ \\
\hline Washed erythrocytes & mmoles $/ \mathrm{ml}$ & $\%$ \\
Washed erythrocytes & 0 & 0 \\
Whole hemolysate & 3.48 & 1.0 \\
Whole hemolysate & 0 & 0 \\
Hemoglobin solution & 3.48 & 5.7 \\
Hemoglobin solution & 0 & 0 \\
& 3.48 & 21.0
\end{tabular}

* Final concentration of hemoglobin: $1.47 \times 10^{-4} \mathrm{M}$ added as washed cells, whole hemolysate, or hemoglobin solution to all flasks. The flasks containing washed erythrocytes also contained enough Krebs-Ringer phosphate buffer to bring the volume to $50 \mathrm{ml}$. The flasks containing whole hemolysate and those containing hemoglobin solution also contained EDTA, $3.42 \times 10^{-4} \mathrm{M}$, added in 0.15 $M$ sodium chloride; $2 \mathrm{ml}$ of $0.4 \mathrm{M}$ phosphate buffer $(\mathrm{pH}$ 7.40 ); and sufficient water and $0.15 \mathrm{M}$ sodium chloride to bring the volume to $8 \mathrm{ml}$ and render it isotonic. Erlenmeyer flasks $(125 \mathrm{ml})$ were used for the experiment with whole cells. Siliconized Erlenmeyer flasks $(50 \mathrm{ml})$ were used for the experiments with whole hemolysates and hemoglobin solutions. Incubations were carried out at $37^{\circ} \mathrm{C}$ in a Dubnoff metabolic shaker at about 100 oscillations per minute. These were single experiments.

of sulfhemoglobin in whole hemolysates but no effect in hemoglobin solutions (Table II).

Effect of ascorbic acid on the formation of oxidative derivatives of hemoglobin in washed red cells. The addition of sodium azide, a catalase
TABLE II

Effect of GSH on sulfhemoglobin formation after one hour of incubation at $37^{\circ} C^{*}$

\begin{tabular}{|c|c|c|}
\hline Substrate & GSH & $\begin{array}{l}\text { Sulfhemo- } \\
\text { globin }\end{array}$ \\
\hline $\begin{array}{l}\text { Whole hemolysate } \\
\text { Whole hemolysate } \\
\text { Hemoglobin solution } \\
\text { Hemoglobin solution }\end{array}$ & $\begin{array}{l}\text { umoles } / \mathrm{ml} \\
\text { none } \\
2.62 \\
\text { none } \\
2.62\end{array}$ & $\begin{array}{r}\% \\
8.5 \\
2.0 \\
22.0 \\
24.3\end{array}$ \\
\hline
\end{tabular}

* Final concentrations of reagents: hemoglobin, 1.47 $\times 10^{-4} \mathrm{M}$, added as whole hemolysate or hemoglobin solution; EDTA, $3.42 \times 10^{-4} \mathrm{M}$, added in $0.15 \mathrm{M}$ sodium chloride. These preceding reagents were added to all flasks. In addition each flask contained $2 \mathrm{ml}$ of $0.4 \mathrm{M}$ phosphate buffer ( $\mathrm{pH} 7.40$ ) and sufficient water and $0.15 \mathrm{M}$ sodium chloride to bring the final volume to $8 \mathrm{ml}$ and render it isotonic: Siliconized Erlenmeyer flasks $(50 \mathrm{ml})$ were used for the incubation, which was carried out at $37^{\circ} \mathrm{C}$ in a Dubnoff metabolic shaker at about 100 oscillations per minute. These were single experiments.

inhibitor, increased the formation of methemoglobin and sulfhemoglobin in the presence of ascorbic acid $(p<0.05)$ (Table III). If, in addition to sodium azide, glucose was added, the formation of oxidative derivatives was reduced significantly $(p<0.05)$. There was no significant loss of hemoglobin in these experiments.

Effect of GSH on the formation of oxidative derivatives of hemoglobin in whole hemolysates. In the presence of either ascorbic acid or acetyl-

TABLE III

Effect of ascorbic acid on the formation of oxidative derivatives of hemoglobin in washed red cells*

\begin{tabular}{|c|c|c|c|c|}
\hline & \multicolumn{4}{|c|}{ Additive } \\
\hline & None & Glucose & Glucose and azide & Azide \\
\hline & \multicolumn{4}{|c|}{$\%$ of total hemoglobin at time zero } \\
\hline Methemoglobin & & & & \\
\hline $\begin{array}{r}0 \mathrm{~min} \\
240 \mathrm{~min}\end{array}$ & $\begin{array}{l}1.0(0.6-1.3) \\
1.4(0.1-2.5)\end{array}$ & $\begin{array}{l}1.1(0.6-1.6) \\
0.4(0.0-0.9)\end{array}$ & $\begin{array}{l}0.8(0.0-1.6) \\
1.4(0.0-1.9)\end{array}$ & $\begin{array}{l}0.4(0.0-0.7) \\
5.1(3.0-8.1)\end{array}$ \\
\hline \multicolumn{5}{|l|}{ Sulfhemoglobin } \\
\hline $\begin{array}{r}0 \mathrm{~min} \\
240 \mathrm{~min}\end{array}$ & $\begin{array}{l}0.5(0.5-0.6) \\
3.2(2.4-4.3)\end{array}$ & $\begin{array}{l}0.3(0.3-0.4) \\
0.4(0.0-1.0)\end{array}$ & $\begin{array}{l}0.1(0.0-0.3) \\
3.4(3.1-3.7)\end{array}$ & $\begin{aligned} 0.5 & (0.5-0.5) \\
13.9 & (11.8-15.9)\end{aligned}$ \\
\hline \multicolumn{5}{|l|}{ Oxyhemoglobin } \\
\hline $\begin{array}{r}0 \mathrm{~min} \\
240 \mathrm{~min}\end{array}$ & $\begin{array}{l}98.7(98.4-99.0) \\
96.0(94.7-97.6)\end{array}$ & $\begin{array}{l}98.7(98.4-99.0) \\
99.2(98.4-99.8)\end{array}$ & $\begin{array}{l}99.1(98.4-99.9) \\
95.9(95.0-97.0)\end{array}$ & $\begin{array}{l}99.2(98.8-99.0) \\
83.1(76.0-88.7)\end{array}$ \\
\hline \multicolumn{5}{|l|}{ Total hemoglobin } \\
\hline $\begin{array}{r}0 \mathrm{~min} \\
240 \mathrm{~min}\end{array}$ & $\begin{array}{l}100.0(100.0-100.0) \\
100.2(99.0-100.8)\end{array}$ & $\begin{array}{l}100.0(100.0-100.0) \\
100.2(99.8-100.4)\end{array}$ & $\begin{array}{l}100.0(100.0-100.0) \\
101.0(100.0-101.5)\end{array}$ & $\begin{array}{l}100.0(100.0-100.0) \\
102.1(100.6-102.8)\end{array}$ \\
\hline
\end{tabular}

* The figures represent the mean and range (parentheses) of four experiments with red cells obtained from one individual. Final concentrations of reagents: ascorbic acid, $1.87 \times 10^{-3} \mathrm{M}$; hemoglobin (added as washed cells), $1.47 \times$ $10^{-4} \mathrm{M}$ (the preceding reagents were added to all flasks); and sodium azide $\left(\mathrm{NaN}_{3}\right), 6.0 \times 10^{-3} \mathrm{M}$. Krebs-Ringer phosphate buffer was added to bring the volume in each flask to $50 \mathrm{ml}$. The mixtures were incubated in 125 -ml Erlenmeyer flasks at $37^{\circ} \mathrm{C}$ in a Dubnoff metabolic shaker at about 140 oscillations per minute. 
TABLE IV

Effect of GSH on the formation of oxidative derivatives of hemoglobin in whole hemolysates incubated with ascorbic acid*

\begin{tabular}{lcc}
\hline & \multicolumn{2}{c}{ Additive } \\
\cline { 2 - 3 } & None & GSH \\
\hline Methemoglobin & $0.8(0.0-1.6)$ & $1.4(1.1-1.7)$ \\
0 min & $8.5(6.9-9.6)$ & $2.0(0.0-4.3)$ \\
60 min & & \\
Sulf hemoglobin & $0.0(0.0-0.0)$ & $0.0(0.0-0.0)$ \\
0 min & $5.7(3.7-8.4)$ & $1.2(0.2-2.8)$ \\
60 min & & \\
Oxyhemoglobin & $99.2(98.4-100.0)$ & $98.6(98.4-98.8)$ \\
0 min & $85.7(82.2-87.4)$ & $97.2(97.0-97.5)$ \\
60 min & & $100.0(100.0-100.0)$ \\
Total hemoglobin & & $100.2(99.8-100.4)$ \\
0 min & $100.0(100.0-100.0)$ & \\
60 min & $99.9(99.5-100.9)$ & \\
\hline
\end{tabular}

* The figures represent the mean and range (parentheses) of three experiments with red cells from one individual. Final concentrations of reagents: ascorbic acid, $3.48 \times 10^{-3} \mathrm{M}$; hemoglobin (added as whole hemolysate), $1.47 \times 10^{-4} \mathrm{M}$; EDTA, $3.42 \times 10^{-4} \mathrm{M}$, added in $0.15 \mathrm{M}$ sodium chloride (the preceding reagents were added to all flasks); and reduced glutathione (GSH), $2.62 \times 10^{-3} \mathrm{M}$, added in $0.15 \mathrm{M}$ sodium chloride. Each flask contained $2 \mathrm{ml}$ of $0.4 \mathrm{M}$ phosphate buffer $(\mathrm{pH}$ 7.40) and sufficient water and $0.15 \mathrm{M}$ sodium chloride to bring the final volume to $8 \mathrm{ml}$ and render it isotonic. Erlenmeyer flasks $(50 \mathrm{ml})$ were used for the incubation, which was carried out in a Dubnoff metabolic shaker at about 70 oscillations per minute at $37^{\circ} \mathrm{C}$.
TABLE V

Effect of GSH on the formation of oxidative derivatives of hemoglobin in whole hemolysates incubated with acetylphenylhydrazine*

\begin{tabular}{ccc}
\hline \hline & \multicolumn{2}{c}{ Additive } \\
\cline { 2 - 3 } & \multicolumn{1}{c}{ None } & GSH \\
\hline & $\%$ of total hemoglobin at time zero \\
Methemoglobin & & $1.2(0.8-2.0)$ \\
0 min & $0.9(0.0-1.4)$ & $5.0(4.6-5.6)$ \\
60 min & $10.6(9.0-11.7)$ & \\
Sulfhemoglobin & & $0.0(0.0-0.0)$ \\
0 min & $0.0(0.0-0.1)$ & $0.1(0.0-0.2)$ \\
60 min & $1.7(1.5-2.0)$ & $98.8(98.0-99.2)$ \\
Oxyhemoglobin & & $96.6(95.0-99.0)$ \\
0 min & $99.2(98.7-100.0)$ & \\
60 min & $89.0(87.3-91.5)$ & $100.0(100.0-100.0)$ \\
Total hemoglobin & & $101.7(100.0-105.6)$ \\
0 min & $100.0(100.0-100.0)$ & \\
60 min & $101.2(99.4-102.0)$ & \\
\hline
\end{tabular}

* The figures represent the mean and range (parentheses) of four experiments with blood from one individual. Final concentrations of reagents: acetylphenylhydrazine, $3.33 \times 10^{-3} \mathrm{M}$; hemoglobin (added as whole hemolysate), $1.47 \times 10^{-4} \mathrm{M}$; EDTA, $3.42 \times 10^{-4} \mathrm{M}$ (added in $0.15 \mathrm{M}$ sodium chloride) (the preceding reagents were added to all flasks); reduced glutathione (GSH), $2.62 \times 10^{-3} \mathrm{M}$ (added in $0.15 \mathrm{M}$ sodium chloride). Each flask contained $2 \mathrm{ml}$ of $0.4 \mathrm{M}$ phosphate buffer ( $\mathrm{pH}$ 7.40) and sufficient water and $0.15 \mathrm{M}$ sodium chloride to bring the final volume to $8 \mathrm{ml}$ and render it isotonic. Fifty-ml siliconized Erlenmeyer flasks were used for the incubation, which was carried out in a Dubnoff metabolic shaker at about 70 oscillations per minute at $37^{\circ} \mathrm{C}$.

TABLE VI

Effect of GSH and NHP on the formation of oxidative derivatives of hemoglobin in hemoglobin solutions incubated with ascorbic acid*

\begin{tabular}{|c|c|c|c|c|}
\hline & \multicolumn{4}{|c|}{ Additive } \\
\hline & None & GSH & GSH and NHP & NHP \\
\hline Methemoglobin & \multicolumn{4}{|c|}{$\%$ of total hemoglobin at time zero } \\
\hline $\begin{array}{c}0 \mathrm{~min} \\
60 \mathrm{~min}\end{array}$ & $\begin{array}{l}0.5(0.0-0.6) \\
10.7(9.7-11.3)\end{array}$ & $\begin{array}{l}0.4(0.0-0.8) \\
8.6(8.5-8.8)\end{array}$ & $\begin{array}{l}0.3(0.0-0.5) \\
9.1(9.0-9.9)\end{array}$ & $\begin{array}{l}0.9(0.0-1.2) \\
13.2(13.1-13.5)\end{array}$ \\
\hline \multicolumn{5}{|l|}{ Sulfhemoglobin } \\
\hline $\begin{array}{r}0 \mathrm{~min} \\
60 \mathrm{~min}\end{array}$ & $\begin{aligned} & 0.0(0.0-0.0)(0.0) \\
& 21.4(20.4-21.9)\end{aligned}$ & $\begin{aligned} 0.0 & (0.0-0.0) \\
24.7 & (20.1-27.0)\end{aligned}$ & $\begin{array}{l}0.0(0.0-0.0) \\
7.8(7.3-8.9)\end{array}$ & $\begin{array}{c}0.0(0.0-0.0) \\
11.7(11.1-12.5)\end{array}$ \\
\hline \multicolumn{5}{|l|}{ Oxyhemoglobin } \\
\hline $\begin{array}{r}0 \mathrm{~min} \\
60 \mathrm{~min}\end{array}$ & $\begin{array}{l}99.5(99.3-100.0) \\
58.0(55.9-63.5)\end{array}$ & $\begin{array}{l}99.6(99.1-100.0) \\
58.8(55.2-65.4)\end{array}$ & $\begin{array}{l}99.7(99.5-100.0) \\
77.6(76.1-77.8)\end{array}$ & $\begin{array}{l}99.1(97.1-99.7) \\
65.6(64.9-67.0)\end{array}$ \\
\hline \multicolumn{5}{|l|}{ Total hemoglobin } \\
\hline $\begin{array}{r}0 \mathrm{~min} \\
60 \mathrm{~min}\end{array}$ & $\begin{array}{r}100.0(100.0-100.0) \\
87.2(85.9-91.7)\end{array}$ & $\begin{array}{r}100.0(100.0-100.0) \\
88.9(88.0-89.1)\end{array}$ & $\begin{array}{r}100.0(100.0-100.0) \\
94.5(93.8-95.6)\end{array}$ & $\begin{array}{c}100.0(100.0-100.0) \\
90.5(90.4-90.6)\end{array}$ \\
\hline \multicolumn{5}{|c|}{ "Precipitated" hemoglobin } \\
\hline $\begin{array}{l}0 \mathrm{~min} \\
60 \mathrm{~min}\end{array}$ & $\begin{array}{c}0.0(0.0-0.0) \\
12.8(8.6-14.1)\end{array}$ & $\begin{array}{c}0.0(0.0-0.0) \\
11.1(8.3-13.7)\end{array}$ & $\begin{array}{l}0.0(0.0-0.0) \\
5.5(4.4-6.2)\end{array}$ & $\begin{array}{l}0.0(0.0-0.0) \\
9.5(9.0-11.0)\end{array}$ \\
\hline
\end{tabular}

* The figures represent the mean and range (parentheses) of four experiments with blood obtained from one individual. Final concentrations of reagents: hemoglobin (added as hemoglobin solution), $1.47 \times 10^{-4} \mathrm{M}$; ascorbic acid, $3.48 \times 10^{-3}$ $\mathrm{M}$; EDTA, $3.42 \times 10^{-4} \mathrm{M}$ (added in $0.15 \mathrm{M}$ sodium chloride) (these reagents were added to all flasks); nonhemoglobin protein (NHP) solution, $0.2 \mathrm{ml} ; \mathrm{GSH}, 2.62 \times 10^{-3} \mathrm{M}$ (added in $0.15 \mathrm{M}$ sodium chloride). Each flask contained $2 \mathrm{ml}$ of $0.4 \mathrm{M}$ phosphate buffer ( $\mathrm{pH}$ 7.40) except those flasks containing NHP; $1.8 \mathrm{ml}$ of buffer was added to these flasks. Flasks contained sufficient $0.15 \mathrm{M}$ sodium chloride and water to bring the final volume to $8 \mathrm{ml}$ and render the solutions isotonic. Fifty-ml siliconized Erlenmeyer flasks were used for the incubation, which was carried out in a Dubnoff metabolic shaker at about 70 oscillations per minute at $37^{\circ} \mathrm{C}$. 
TABLE VII

Effect of GSH and NHP on the formation of oxidative derivatives of hemoglobin in hemoglobin solutions incubated with acetylphenylhydrazine*

\begin{tabular}{|c|c|c|c|c|}
\hline & \multicolumn{4}{|c|}{ Additive } \\
\hline & None & GSH & GSH and NHP & NHP \\
\hline Methemerlohin & \multicolumn{4}{|c|}{$\%$ of total hemoglobin at time zero } \\
\hline $\begin{array}{l}0 \mathrm{~min} \\
60 \mathrm{~min}\end{array}$ & $\begin{aligned} 0.7 & (0.0-1.5) \\
32.1 & (29.8-36.1)\end{aligned}$ & $\begin{aligned} 0.7 & (0.0-1.2) \\
33.5 & (31.8-36.7)\end{aligned}$ & $\begin{array}{c}0.7(0.0-1.3) \\
12.6(7.4-20.5)\end{array}$ & $\begin{array}{c}0.6(0.0-1.1) \\
29.2(25.6-32.6)\end{array}$ \\
\hline \multicolumn{5}{|l|}{ Sulfhemoglobin } \\
\hline $\begin{array}{l}0 \mathrm{~min} \\
60 \mathrm{~min}\end{array}$ & $\begin{aligned} 3.2(1.6-4.2) \\
13.9(12.5-14.7)\end{aligned}$ & $\begin{array}{l}0.5(0.0-1.3) \\
13.2(11.8-15.9)\end{array}$ & $\begin{array}{l}0.2(0.0-0.8) \\
2.4(0.7-4.0)\end{array}$ & $\begin{array}{c}2.2(0.9-3.7) \\
12.6(10.4-14.9)\end{array}$ \\
\hline \multicolumn{5}{|l|}{ Oxyhemoglobin } \\
\hline $\begin{array}{c}0 \mathrm{~min} \\
60 \mathrm{~min}\end{array}$ & $\begin{array}{l}96.1(94.8-98.4) \\
43.4(36.4-46.4)\end{array}$ & $\begin{array}{l}98.8(97.6-100.0) \\
44.6(37.4-48.1)\end{array}$ & $\begin{array}{l}99.1(98.1-100.0) \\
82.5(73.4-89.6)\end{array}$ & $\begin{array}{l}97.2(95.3-99.1) \\
51.1(45.3-55.9)\end{array}$ \\
\hline \multicolumn{5}{|l|}{ Total hemoglobin } \\
\hline $\begin{array}{l}0 \mathrm{~min} \\
60 \mathrm{~min}\end{array}$ & $\begin{array}{c}100.0(100.0-100.0) \\
89.4(84.0-93.3)\end{array}$ & $\begin{aligned} 100.0 & (100.0-100.0) \\
91.4 & (88.7-92.5)\end{aligned}$ & $\begin{aligned} 100.0 & (100.0-100.0) \\
97.5 & (94.9-98.9)\end{aligned}$ & $\begin{array}{r}100.0(100.0-100.0) \\
92.9(89.0-96.5)\end{array}$ \\
\hline \multicolumn{5}{|c|}{ "Precipitated" hemoglobin } \\
\hline $\begin{array}{l}0 \mathrm{~min} \\
60 \mathrm{~min}\end{array}$ & $\begin{array}{c}0.0(0.0-0.0) \\
10.6(9.4-11.7)\end{array}$ & $\begin{array}{l}0.0(0.0-0.0) \\
8.6(8.0-9.9)\end{array}$ & $\begin{array}{l}0.0(0.0-0.0) \\
2.5(0.5-3.6)\end{array}$ & $\begin{array}{l}0.0(0.0-0.0) \\
7.1(6.0-8.2)\end{array}$ \\
\hline
\end{tabular}

* The figures represent the mean and range (parentheses) of five experiments with blood obtained from four individuals. Final concentrations of reagents: hemoglobin (added as hemoglobin solution), $1.47 \times 10^{-4} \mathrm{M}$; acetylphenylhydrazine, $1.2 \times 10^{-3} \mathrm{M}$; EDTA, $3.42 \times 10^{-4} \mathrm{M}$ (added in $0.15 \mathrm{M}$ sodium chloride) (these preceding reagents were added to all flasks); nonhemoglobin protein (NHP) solution, $0.2 \mathrm{ml}$; and GSH, $2.62 \times 10^{-3} \mathrm{M}$ (added in $0.15 \mathrm{M}$ sodium chloride). Each flask contained $2 \mathrm{ml}$ of $0.4 \mathrm{M}$ phosphate buffer $(\mathrm{pH} 7.40$ ) except those flasks containing NHP. To these flasks $1.8 \mathrm{ml}$ of buffer was added. Flasks contained sufficient $0.15 \mathrm{M}$ sodium chloride and water to bring the final volume to $8 \mathrm{ml}$ and render the solutions isotonic. Fifty-ml siliconized Erlenmeyer flasks were used for the incubations, which were carried out in a Dubnoff metabolic shaker at about 70 oscillations per minute at $37^{\circ} \mathrm{C}$.

phenylhydrazine, the formation of methemoglobin and sulfhemoglobin was significantly less and the preservation of oxyhemoglobin was significantly greater when GSH was added to the incubation mixtures (Tables IV and V).

Effect of GSH and NHP on the formation of oxidative derivatives of hemoglobin in hemoglobin solutions. Hemoglobin solutions differed from whole hemolysates in that they lacked NHP. In hemoglobin solutions incubated with ascorbic acid, the addition of GSH without NHP provided some protection against the formation of methemoglobin $(p<0.05)$ but none against the formation of sulfhemoglobin or precipitated hemoglobin. GSH alone resulted in no increase in the preservation of oxyhemoglobin. NHP provided a significant $(p<0.05)$ reduction in the amount of sulfhemoglob:n formed and in the amount of oxyhemoglobin preserved but did not affect the amount of hemoglobin precipitated. The combination of GSH and NHP was no more effective than GSH alone in protecting against the formation of methemoglobin, but the combination was more effective than GSH in protecting against the
TABLE VIII

Effect of GSH and NHP on the amount of hemoglobin precipitated from solutions of hemoglobin incubated for one hour with acetylphenylhydrazine*

\begin{tabular}{lc}
\hline \hline Additive & $\begin{array}{c}\text { Initial } \\
\text { hemoglobin } \\
\text { precipitated }\end{array}$ \\
\hline & $\%$ \\
None & 2.3 \\
GSH & 2.0 \\
GSH and NHP & 0.0 \\
NHP & 6.4
\end{tabular}

* Final concentrations of reagents: hemoglobin (added as hemoglobin solution), $1.47 \times 10^{-4} \mathrm{M}$; acetylphenylhydrazine, $1.20 \times 10^{-3} \mathrm{M}$; EDTA, $3.42 \times 10^{-4} \mathrm{M}$ (added in $0.15 \mathrm{M}$ sodium chloride) (these preceding reagents were added to all flasks); nonhemoglobin protein (NHP) solution, $0.2 \mathrm{ml}$; and GSH, $2.62 \times 10^{-3} \mathrm{M}$ (added in $0.15 \mathrm{M}$ sodium chloride). Each flask contained $2 \mathrm{ml}$ of $0.4 \mathrm{M}$ phosphate buffer ( $\mathrm{pH} 7.40$ ) except those flasks containing NHP, which contained only $1.8 \mathrm{ml}$. Flasks also contained sufficient $0.15 \mathrm{M}$ sodium chloride and water to bring the final volume to $8 \mathrm{ml}$ and render the solutions isotonic. The incubation was carried out in cellulose nitrate ultracentrifuge tubes that were dried to constant weight before the experiment. The tubes were incubated at $37^{\circ} \mathrm{C}$ in a Dubnoff metabolic shaker at about 100 oscillations per minute. At the end of the incubation period, the tubes were centrifuged at $144,000 \times g$ for 1 hour. The supernatant solution was decanted, the precipitate was washed in water, and the centrifugation was repeated. The tubes were again dried to constant weight in a desiccator. 


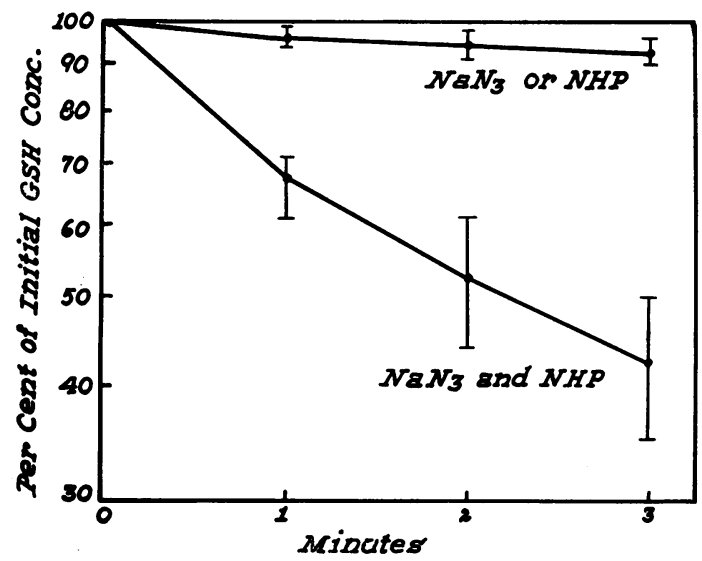

Fig. 1. Effect of NHP on GSH in solution with HYDROGEN PEROXIDE AND SODIUM AZIDE. Final concentrations of reagents: GSH, $4.66 \times 10^{-4} \mathrm{M}$ (added in $0.4 \mathrm{M}$ phosphate buffer, pH 7.1) ; EDTA, $1.34 \times 10^{-4} \mathrm{M}$ (added in $0.4 \mathrm{M}$ phosphate buffer, $\mathrm{pH} 7.1$ ); and hydrogen peroxide, $3.0 \times 10^{-4} \mathrm{M}$. The preceding reagents were present in all tubes. NHP (nonhemoglobin protein) solution added was $0.1 \mathrm{ml} ; \mathrm{NaN}_{3}, 2 \times 10^{-2} \mathrm{M}$. Phosphate buffer, $0.4 \mathrm{M}, \mathrm{pH} 7.1,0.5 \mathrm{ml}$, was added to the reagent blank in place of GSH. The incubation was carried out in $10-\times$ $150-\mathrm{mm}$ siliconized test tubes at $37^{\circ} \mathrm{C}$ in a water bath without shaking. All reagents were warmed to $37^{\circ} \mathrm{C}$ before the experiment, and the reaction was timed from the addition of hydrogen peroxide.

The solid dots represent the mean values for six experiments performed on two specimens from each of three subjects. The vertical lines show the ranges of values.

formation of sulfhemoglobin and precipitated hemoglobin and in the preservation of oxyhemoglobin (Table VI). Dialysis of NHP against $1,000 \mathrm{vol}$ of deionized water at $8^{\circ} \mathrm{C}$ for 36 hours did not remove its protective effect; however, it was inactivated by standing 72 hours at $22^{\circ} \mathrm{C}$.

In solutions incubated with acetylphenylhydrazine, GSH alone provided no protection. NHP alone provided some protection against the formation of methemoglobin and sulfhemoglobin and in the preservation of oxyhemoglobin $(p<0.05)$ but did not protect against the formation of "precipitated" hemoglobin. The combination of GSH with NHP provided more protection than NHP alone against the formation of methemoglobin, sulfhemoglobin, and "precipitated" hemoglobin and was more effective in preserving oxyhemoglobin $(\mathrm{p}<0.05)$ (Table VII).

Effect of GSH and NHP on the formation of precipitated hemoglobin in hemoglobin solutions incubated with acetylphenylhydrazine. In a single experiment, in which the amount of hemoglobin precipitated was actually weighed, GSH had some effect in reducing the amount of hemoglobin precipitated, but NHP alone actually seemed to increase the amount of hemoglobin precipitated; when both GSH and NHP were added, no hemoglobin was precipitated (Table VIII).

Effect of NHP on GSH in the presence of hydrogen peroxide. Hydrogen peroxide alone was found to produce only a slow fall in the concentration of GSH in solution, nor was this altered by the addition of either NHP or sodium azide individually (Figure 1). The addition, however, of both NHP and sodium azide at the same time accelerated the disappearance of GSH in the presence of hydrogen peroxide. The rate of fall of GSH concentration in the tubes with NHP and sodium azide was significantly different from the control tubes at 1,2 , and 3 minutes $(p<0.001)$. The conversion of GSH to its oxidized disulfide form (GSSG) was measured in a single similar experiment. Six and one-half $\mu$ moles of GSH and $0.35 \mu$ mole of GSSG were present at the beginning of the reaction. Eight minutes later there were $0.7 \mu$ mole of GSH and $3.2 \mu$ moles of GSSG (Figure 2).

The factor in the NHP solution which catalyzed this reaction was not removed by dialysis against $1,000 \mathrm{vol}$ of deionized water at $4^{\circ} \mathrm{C}$ for 36 hours ; it was, however, inactivated by incubation at $70^{\circ} \mathrm{C}$ for 1 hour or at $22^{\circ} \mathrm{C}$ for 72 hours or by the addition of 1 vol of $10 \%$ trichloroacetic acid

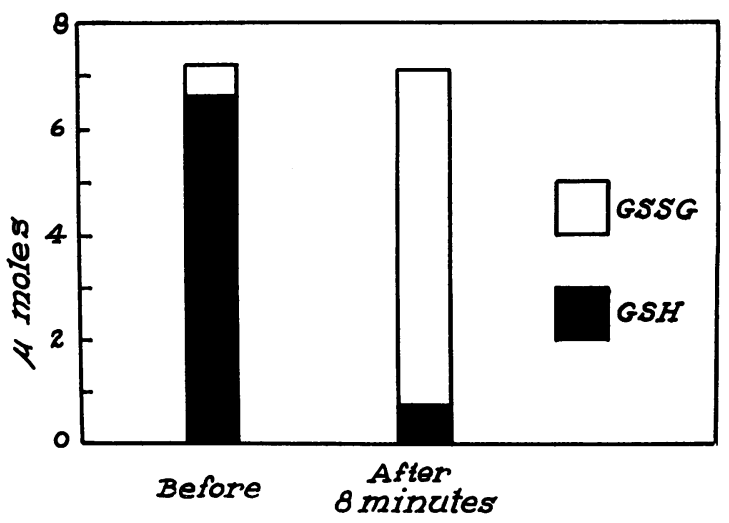

Fig. 2. Oxidation of GSH to GSSG by NHP and HYDROGEN PEROXIDE. The results are expressed as micro. moles of sulfhydryl. The experiment was carried out under the same conditions as those described for Figure 1. 
followed by neutralization of the excess acidity.

Presence of protective activity in various types of hemoglobin preparations. Crystals of hemoglobin, prepared by the method of Drabkin (30), substituted for NHP solution in the conversion of GSH to GSSG in the presence of hydrogen peroxide and azide (Table IX). In contrast, the hemoglobin solution prepared by the method outlined in this report was free of the protective activity (Tables VI-VIII), which we were able to separate into the NHP solution.

\section{Discussion}

Several limitations of our methods deserve comment. Sulfhemoglobin as determined by the Evelyn-Malloy procedure is probably not a specific substance but rather a group of pigments, derived from oxidation of hemoglobin, having in common an absorption peak at $620 \mathrm{~m} \mu$ which is not abolished by the addition of cyanide. The addition of azide to solutions containing methemoglobin results in the formation of an azide-methemoglobin complex with an absorption maximum at 620 to $635 \mathrm{~m} \mu$. This common absorption peak makes the precise determination of methemoglobin and sulfhemoglobin difficult, but the formation of brown derivatives of hemoglobin can be compared in the presence or absence of glucose when equal amounts of azide are present. However, azide was added in only one experiment (Table III) in which methemoglobin and sulfhemoglobin were measured. Finally, the indirect determination of precipitated hemoglobin obtained by subtracting the measured total hemoglobin from the hemoglobin at time zero must be considered to be only semiquantitative. Recognizing these limitations of our studies, our measurements of methemoglobin, sulfhemoglobin, oxyhemoglobin, and total hemoglobin provide as good a measure of the oxidation of hemoglobin as is presently available.

Hemoglobin, when exposed to air in vitro, will form the oxidation products, methemoglobin and sulfhemoglobin, and will eventually precipitate (31). Among the mechanisms for prevention of this occurrence in the normal erythrocyte in vivo (13), despite the presence of oxygen in the blood, are systems involving methemoglobin reductase $(32,33)$ and, possibly, catalase. Catalase can protect hemoglobin from oxidation in vitro (12);
TABLE IX

The effect of various hemoglobin solutions on GSH in solution with hydrogen peroxide and sodium azide*

\begin{tabular}{lcc}
\hline \hline & \multicolumn{2}{c}{$\begin{array}{c}\% \text { of initial } \\
\text { GSH remaining }\end{array}$} \\
\cline { 2 - 3 } & 0 min & 7 min \\
\hline Control & 100 & 90 \\
Hemoglobin solution & 100 & 90 \\
Drabkin's hemoglobin & 100 & 63 \\
\hline
\end{tabular}

* Final concentrations of reagents: GSH, $4.66 \times 10^{-4} \mathrm{M}$ (added in $0.4 \mathrm{M}$ phosphate buffer, $\mathrm{pH} 7.1$ ); hydrogen peroxide, $3.0 \times 10^{-4} \mathrm{M}$; EDTA, $1.34 \times 10^{-4} \mathrm{M}$ (added in $0.4 \mathrm{M}$ phosphate buffer, $\mathrm{pH} 7.1) ; \mathrm{NaN}_{3}, 2.0 \times 10^{-2} \mathrm{M}$ (these preceding reagents were present in all flasks); and hemoglobin solutions (prepared as indicated above), 1.47

$\times 10^{-4} \mathrm{M}$. The control tube contained an equivalent amount of demineralized water in place of hemoglobin solution. The incubation was carried out in $10-\times 150-\mathrm{mm}$ siliconized test tubes at $37^{\circ} \mathrm{C}$ in a water bath without shaking. All reagents were warmed to $37^{\circ} \mathrm{C}$ before the experiment, and the reaction was timed from the addition of hydrogen peroxide. These were single experiments.

this can also be deduced from the consequence of its inhibition with azide in vitro (Figure 1). However, the reality and importance of this protection in vivo may be questioned for these reasons: 1) small amounts of hydrogen peroxide delivered continuously in vitro will not oxidize hemoglobin despite the absence of normal catalase activity until GSH is removed $(34) ; 2$ ) individuals with acatalasemia have not been reported to have methemoglobinemia or sulfhemoglobinemia $(35,36)$; and 3$)$ oxidation products of hemoglobin may accumulate in diseases of people with normal erythrocytic catalase and methemoglobinreductase but with low or unstable erythrocytic GSH (37).

The existence of an additional mechanism, protecting hemoglobin from oxidation when catalase is inhibited and requiring both GSH and an erythrocyte enzyme, was suggested by Mills in studies of bovine and rat blood $(7,8)$ and has been confirmed by our observations in humans.

The report of Allen and Jandl (10) that GSH, without the addition of other factors, would protect crystalline human hemoglobin from oxidation may be reconciled with the findings reported here. We have found that hemoglobin prepared as described by Drabkin (30) contained glutathione peroxidase activity. Hemoglobin solution prepared by our method was devoid of glutathione peroxidase activity. GSH alone, therefore, had little or no protective effect. 
The report of Szeinberg and Marks (11) that GSH failed to protect human hemoglobin from oxidation could have been due to the rapid autoxidation of GSH in their preparations, especially if trace amounts of copper were present (38). Their success in using TPNH rather than GSH may be attributed to the system intact in their experiments for continuously regenerating GSH from GSSG, although TPN and TPNH may also have a protective effect that is unrelated to GSH. In our experiments, we found necessary the use of fresh solutions of GSH in deionized water, and EDTA (10) had to be added to assure removal of trace amounts of copper and to avoid nonenzymatic oxidation of GSH. TPNH can be excluded as an active factor in our preparations, since it disappears rapidly in hemolysates; glucose was not added to enable its regeneration, and any preformed TPNH would have been removed from our preparations since it is dialyzable. A further indication that TPNH was not present in our preparations is that we were unable to demonstrate glutathione reductase activity unless TPNH was added. Because of the lack of TPNH in the test system, we can exclude the possibility that the protective effect of the NHP solution was due to a continuing supply of GSH from the glutathione reductase.

The progressive enhancement of ascorbic acid's ability to effect oxidation of hemoglobin by dissolution of erythrocytes in the preparation of hemolysate and then removal of erythrocytic enzymes from the hemolysate in preparation of the hemoglobin solution suggests of itself that an enzymatic mechanism, rather than an uncatalyzed chemical reaction, is involved in protecting hemoglobin from oxidation.

That similar results were obtained when either acetylphenylhydrazine or ascorbic acid was used as the oxidant compound should not be interpreted as indicating that the mechanism of oxidation by the two compounds is the same in each case. The coupled oxidation of hemoglobin and ascorbic acid is enhanced by catalase inhibitors such as azide and cyanide (39). Such enhancement has not been demonstrated with acetylphenylhydrazine. Furthermore, acetylphenylhydrazine causes hemolysis of erythrocytes in vivo, whereas ascorbic acid does not. Our studies indicate that the GSHperoxidase system is involved in protection of he- moglobin from oxidation in vitro by both mechanisms.

The protective effect of the NHP solution was nondialyzable but lost on standing at $20^{\circ} \mathrm{C}$ for 72 hours or after a brief period of moderate heat $\left(70^{\circ} \mathrm{C}\right)$ or after treatment with a protein precipitant. This suggests that the activity under consideration could be attributed to a protein. Acceleration of the oxidation of GSH when both hydrogen peroxide and the active NHP solution were present, but not with either alone (Figure 1 ), indicates that hydrogen peroxide is a substrate of the reaction, that the NHP solution may contain a peroxidase, and that the reaction would proceed, as suggested earlier (8),

$$
2 \mathrm{GSH}+\mathrm{H}_{2} \mathrm{O}_{2} \rightarrow \mathrm{GSSG}+2 \mathrm{H}_{2} \mathrm{O} \text {. }
$$

It is of interest in this regard that Cohen and Hochstein (40) have recently demonstrated the generation of hydrogen peroxide in red cells incubated with primaquine.

We propose that the action of the enzymatic system in the in vitro protection of hemoglobin from oxidation might be as follows. In the presence of agents capable of oxidizing either hemoglobin or GSH, the enzyme enables preferential oxidation of GSH, sparing the hemoglobin. GSSG would then be reduced by the previously described pathway (5) involving glutathione reductase and G6PD for the generation of TPNH.

Thus, four lesions in the glutathione pathway might interfere with the protection of hemoglobin against oxidation. The clinical occurrence of three of these has been described: 1) G6PD deficiency $(41), 2)$ deficiency of glutathione reductase (42), and 3) deficiency of GSH, where G6PD and glutathione reductase were normal (1). The fourth possibility has not yet been reported; however, one might suspect that the accumulation of oxidation products of hemoglobin would occur in vivo, as has been shown here in vitro, if there is a deficiency of glutathione peroxidase even in the presence of a sufficient supply of GSH.

\section{Summary}

1. The oxidation of hemoglobin to sulfhemoglobin was accelerated in the presence of ascorbic acid. This augmentation was of small measure when fresh erythrocytes were used. of moderate 
degree in fresh whole hemolysates, and of greatest magnitude in hemoglobin solutions free of most erythrocytic enzymes. In the first instance inhibition of catalase enhanced the oxidative change.

2. Reduced glutathione had little protective effect on the oxidation of human hemoglobin in the presence of ascorbic acid or acetylphenylhydrazine unless a heat labile, nondialyzable, erythrocytic, nonhemoglobin protein factor was present.

3 . The existence of a glutathione peroxidase activity in human erythrocytes has been demonstrated. This supports its earlier demonstration in erythrocytes of lower mammals.

4. We suggest that in the presence of oxidizing agents, in vitro, glutathione peroxidase mediates the preferential oxidation of glutathione rather than of hemoglobin, as might otherwise occur; and that Heinz bodies or met-sulfhemoglobin formation in vivo may result if there is a defect in this enzyme, even when the production of reduced glutathione is intact.

\section{Acknowledgment}

The technical assistance of Miss Jacqueline Thomas is gratefully acknowledged.

\section{References}

1. Townes, P. L., and M. Morrison. Investigation of the defect in a variant of hereditary methemoglobinemia. Blood 1961, 19, 60.

2. Oort, M., J. A. Loos, and H. K. Prins. Hereditary absence of reduced glutathione in the erythrocytes -a new clinical and biochemical entity? Preliminary communication. Vox Sang. (Basel) 1961, 6, 370.

3. Scott, J. L., A. Haut, G. E. Cartwright, and M. M. Wintrobe. Congenital hemolytic disease associated with red cell inclusion bodies, abnormal pigment metabolism and an electrophoretic hemoglobin abnormality. Blood 1960, 16, 1239.

4. Hill, A. S., Jr., A. Haut, G. E. Cartwright, and M. M. Wintrobe. Studies of glutathione in hemolytic anemia with inclusion bodies. In preparation.

5. Beutler, E. Drug induced hemolytic anemia (primaquine sensitivity) in The Metabolic Basis of Inherited Disease, J. B. Stanbury, J. B. Wyngaarden, and D. S. Fredrickson, Eds. New York, McGrawHill, 1960, p. 1031.

6. Zinkham, W. H., and R. E. Lenhard, Jr. Metabolic abnormalities of erythrocytes from patients with congenital nonspherocytic hemolytic anemia. J. Pediat. 1959, 55, 319.
7. Mills, G. C., and H. P. Randall. Hemoglobin catabolism II. The protection of hemoglobin from oxidative breakdown in the intact erythrocyte. J. biol. Chem. 1958, 232, 589.

8. Mills, G. C. Hemoglobin catabolism I. Glutathione peroxidase, an erythrocyte enzyme which protects hemoglobin from oxidative breakdown. J. biol. Chem. 1957, 229, 189.

9. Mills, G. C. The purification and properties of glutathione peroxidase of erythrocytes. J. biol. Chem. 1959, 234, 502.

10. Allen, D. W., and J. H. Jandl. Oxidative hemolysis and precipitation of hemoglobin II. Role of thiols in oxidant drug action. J. clin. Invest. 1961, 40, 454.

11. Szeinberg, A., and P. A. Marks. Substances stimulating glucose catabolism by the oxidative reactions of the pentose phosphate pathway in human erythrocytes. J. clin. Invest. 1961, 40, 914.

12. Foulkes, E. C., and R. Lemberg. The formation of choleglobin and the role of catalase. Proc. roy. Soc. B 1949, 136, 435.

13. Wintrobe, M. M. Clinical Hematology, 5th ed. Philadelphia, Lea \& Febiger, 1961, p. 128.

14. London, I. M. The Metabolism of the Erythrocyte. New York, Academic Press, 1961.

15. Hennessey, M. A., A. M. Haffner, and B. W. Gabrio. The separation of erythrocyte enzymes from hemoglobin. Fed. Proc. 1960, 19, 65.

16. Hennessey, M. A., A. M. Waltersdorph, F. M. Huennekens, and B. W. Gabrio. Erythrocyte metabolism. VI. Separation of erythrocyte enzymes from hemoglobin. J. clin. Invest. 1962, 41, 1257.

17. Boyer, P. D. Spectrophotometric study of the reaction of protein sulfhydryl groups with organic mercurials. J. Amer. chem. Soc. 1954, 76, 4331.

18. Grunert, R. R., and P. H. Phillips. A modification of the nitro-prusside method for analysis of glutathione. Arch. Biochem. 1951, 30, 217.

19. Beutler, E. The glutathione instability of drug-sensitive red cells. A new method for the in vitro detection of drug sensitivity. J. Lab. clin. Med. 1957, 49, 84.

20. Dohan, J. S., and G. E. Woodward. Electrolytic reduction and determination of oxidized glutathione. J. biol. Chem. 1939, 129, 393.

21. Evelyn, K. A., and H. T. Malloy. Microdetermination of oxyhemoglobin, methemoglobin and sulfhemoglobin in a single sample of blood. J. biol. Chem. 1938, 126, 655.

22. Takahara, S., H. B. Hamilton, J. V. Neel, T. Y. Kobara, Y. Ogura, and E. T. Nishimura. Hypocatalasemia: a new genetic carrier state. J. clin. Invest. 1960, 39, 610.

23. Kornberg, A., and B. L. Horecker. Glucose-6-phosphate dehydrogenase in Methods in Enzymology, S. P. Colowick and N. O. Kaplan, Eds. New York, Academic Press, 1955, vol. 1, p. 323.

24. Marks, P. A., A. Szeinberg, and J. Banks. Erythrocyte glucose-6-phosphate dehydrogenase of normal 
and mutant human subjects. J. biol. Chem. 1961, 236, 10.

25. Bucher, T., and G. Pfleiderer. Pyruvate kinase from muscle in Methods in Enzymology, S. P. Colowick and N. O. Kaplan, Eds. New York, Academic Press, 1955, vol. 1, p. 435.

26. Valentine, W. N., K. R. Tanaka, and S. Miwa. A specific erythrocytic glycolytic enzyme defect (pyruvate kinase) in three subjects with congenital non-spherocytic hemolytic anemia. Trans. Ass. Amer. Phycns 1961, 74, 100.

27. Wilbur, K. M., and N. G. Anderson. Electrometric and colorimetric determination of carbonic anhydrase. J. biol. Chem. 1948, 176, 147.

28. Schrier, S. L., R. W. Kellermeyer, P. E. Carson, C. E. Ickes, and A. S. Alving. The hemolytic effect of primaquine IX. Enzymatic abnormalities in primaquine-sensitive erythrocytes. J. Lab. clin. Med. 1958, 52, 109.

29. Croxton, F. E. Elementary Statistics with Applications in Medicine. New York, Prentice-Hall, 1953.

30. Drabkin, D. L. Spectrophotometric studies XIV. The crystallographic and optical properties of hemoglobin in man in comparison with those of other species. J. biol. Chem. 1946, 164, 703.

31. Jandl, J. H., L. K. Engle, and D. W. Allen. Oxidative hemolysis and precipitation of hemoglobin. I. Heinz body anemias as an acceleration of red cell aging. J. clin. Invest. 1960, 39, 1818.

32. Gibson, $Q$. H. The reduction of methaemoglobin in red blood cells and studies on the cause of idiopathic methaemoglobinæmia. Biochem. J. 1948, 42, 13.
33. Scott, E. M., and D. D. Hoskins. Hereditary methemoglobinemia in Alaskan Eskimos and Indians. Blood 1958, 13, 795.

34. Cohen, G., and P. Hochstein. Hydrogen peroxide detoxification in acatalasic and normal erythrocytes. Fed. Proc. 1962, 21, 69.

35. Takahara, S. Acatalasemia (lack of catalase in blood) and oral progressive gangrene. Proc. Jap. Acad. 1951, 27, 295.

36. Wyngaarden, J. B., and R. R. Howell. Acatalasia in The Metabolic Basis of Inherited Disease, J. B. Stanbury, J. B. Wyngaarden, and D. S. Fredrickson, Eds. New York, McGraw-Hill, 1960, p. 1398.

37. Carson, P. E., and A. R. Tarlov. Biochemistry of hemolysis in Annual Review of Medicine, D. A. Rytand and W. P. Creger, Eds. Palo Alto, Annual Reviews, 1962, vol. 13, p. 105.

38. Barren, E. S. G. Thiol groups of biological importance. Advanc. Enzymol. 1951, 11, 201.

39. Lemberg, R., and J. W. Legge. Hematin Compounds and Bile Pigments. New York, Interscience Publishers, 1949.

40. Cohen, G., and P. Hochstein. Primaquine-induced generation of hydrogen peroxide in erythrocytes (abstract). Blood 1962, 20, 785.

41. Tarlov, A. R., G. J. Brewer, P. E. Carson, and A. S. Alving. Primaquine sensitivity. Glucose-6-phosphate dehydrogenase deficiency: an inborn error of metabolism of medical and biological significance. Arch. intern. Med. 1962, 109, 209.

42. Carson, P. E., G. J. Brewer, and C. Ickes. Decreased glutathione reductase with susceptibility to hemolysis (abstract). J. Lab. clin. Med. 1961, 58, 804.

\section{SPECIAL NOTICE TO SUBSCRIBERS}

Post Offices will no longer forward the Journal when you move.

Please notify The Journal of Clinical Investigation, Business Office, 10 Stoughton Street, Boston 18, Mass., at once when you have a change of address, and do not omit the Zip Code number if there is one. 